ZOOLOGIA 30 (6): 645-651, December, 2013

http://dx.doi.org/10.1590/S1984-46702013005000003

\title{
Feeding ecology of stream-dwelling Characidae (Osteichthyes: Characiformes) from the upper Tocantins River, Brazil
}

\author{
Maíra Moraes ${ }^{1}$, Carla Ferreira Rezende ${ }^{2} \&$ Rosana Mazzoni ${ }^{1,3}$
}

\author{
${ }^{1}$ Departamento de Ecologia, Instituto de Biologia Roberto Alcantara Gomes, Universidade do Estado do Rio de Janeiro. \\ Rua São Francisco Xavier 524, 20550-013 Rio de Janeiro, RJ, Brazil. \\ ${ }^{2}$ Departamento de Biologia, Centro de Ciências, Universidade Federal do Ceará. Avenida da Universidade 2853, \\ 60020-181 Fortaleza, CE, Brazil. \\ ${ }^{3}$ Corresponding author. E-mail: mazzoni@uerj.br
}

\begin{abstract}
In this contribution we studied the trophic ecology of four Characidae species from the Cavalo Stream, upper Tocantins River, considering diet overlap and trophic niche breadth. The diet of the four species was composed of adult and immature insects, both autochthonous and allochthonous in origin. Autochthonous items dominated the diet of Moenkhausia dichroura (Kner, 1858), Bryconamericus sp., and Creagrutus atrisignum Myers, 1917. By contrast, allochthonous items were dominant in the diet of Astyanax bimaculatus (Linnaeus, 1758). Trophic niche breadth varied among species, with the highest value recorded for M. dichroura (0.48), followed by Bryconamericus sp. (0.39), A. bimaculatus (0.33) and C. atrisignum (0.29). Similarity analysis revealed two groups with different patterns of food preference. The first group was composed of insectivorous and the second by omnivorous species. The overlap in food items consumed by the four species studied was high. We suggest that resources are not limited in this stream and that competition might not be regulating these populations. This is one more case corroborating the general pattern registered for Tropical environments, where resource partitioning and specialization are responsible by the organization of fish communities.
\end{abstract}

KEY WORDS. Allochthonous; autochthonous; niche; resource; stream.

Fish communities are excellent models to test theoretical concepts about resource partitioning (ARANHA et al. 1998, 2000, MotTa \& Uieda 2004), niche breadth (CASATti 2002) and niche overlap (Douglas \& Matthews 1992, Douglas et al. 1994, NovAKowski et al. 2008). Although stream-dwelling fish species consume a variety of food items available in their surroundings, competition does not seem to take place among them. It has been suggested that trophic specialization (Vојтесн et al. 2002, Dyer et al. 2010) or resource partitioning (HyNes 1970, SCHOENER 1974, Ross 1986, DYER et al. 2010) are responsible for this lack of competition. Several studies carried out in tropical aquatic systems have demonstrated that one food resource can be consumed by many different fish species in a community. It may also happen that many species will explore different resources (e.g., Pouilly et al. 2003, 2004, 2006, Novakowski et al. 2008).

The coexistence of species in highly diverse communities has been explained by two main theories (Gravel et al. 2006). The first one, called "the niche theory", considers that a niche is composed of different elements that supply the demands of a species and absorb the impacts of that species on the environment (Chase \& Leibold 2003, Nobis \& Wohlgemuth 2004, MikKelson 2005). In this context, niche differences among species are fundamental to explain the maintenance of biodiversity in different scales (Leibold \& McPeeк 2006). The second theory, called "the neutral theory", claims that species diversity in a given area is the result of stochastic ecological and evolutionary factors that interact on both local and regional scales. The neutral theory renders the niche theory unnecessary for understanding patterns of species coexistence (Hubbell 2001).

Studies conducted in different streams indicate that both theories can be used to explain the patterns of organization of many Neotropical stream-dwelling fish communities. The soaring trophic plasticity of these communities allows them to coexist while exploring variable food supplies (BALAsSA et al. 2004). Resource partitioning and exploratory tactics to minimize feeding overlap, which represent alternatives to competition, are made possible by the great diversity of food items available, the great diversity of morphological adaptations, and the exploration of different microhabitats and periods of activity of species (Hurlbert 1978, Chase \& Leibold 2003).

Species of Characidae are largely widespread and morphologically diversified (BRITSKI et al. 1999). The family is composed of many species (NeLSON 1994), and many cases of trophic resource partitioning have been documented for them (UiedA et al. 1997). The ictiofauna of the Cavalo stream, located at the upper Tocantins River, has 36 fish species. Of these, 10 ( 28\%) are Characiformes and four belong to the Characidae. The 
population densities of the following species, which are found throughout the stream, are the highest among Characidae Astyanax bimaculatus (Linnaeus, 1758), Bryconamericus sp., Creagrutus atrisignum Myers, 1927, and Moenkhausia dichroura (Kner, 1858) - (Miranda \& Mazzoni 2003). The species selected for the present study were the most abundant and widespread in the studied stream.

The four Characidae mentioned above had been previously classified into different feeding guilds, depending on the study site and the composition of the community where they had been found. The objective of this study was to evaluate the trophic ecology of these species at the Cavalo stream. We considered interspecific variations in diet composition, diet overlap, and trophic niche breadth.

\section{MATERIAL AND METHODS}

The Cavalo Stream $\left(14^{\circ} 26^{\prime} 12^{\prime \prime} \mathrm{S}, 48^{\circ} 34^{\prime} 53^{\prime \prime} \mathrm{W}\right)$ is a $3^{\text {rd }}$ order tributary of the Traíras River in the upper Tocantins Basin $\left(14^{\circ} 40^{\prime} \mathrm{S}\right.$, $49^{\circ} 00^{\prime} \mathrm{W}$ and $\left.13^{\circ} 10^{\prime} \mathrm{S}, 48^{\circ} 00^{\prime} \mathrm{W}\right)$. Samples were collected on a $150 \mathrm{~m}$ long stretch of the Cavalo Stream, at a site formed by rocky substrata of riffle and rapid zones interspersed by sandy-mud pools. The marginal vegetation was sparse and the canopy covered approximately $90 \%$ of the study site (Miranda \& MaZzonI 2003).
The hydrological regimen of the upper Tocantins River Basin is well defined (CARAMASCHI et al. 2012), with the high tide season extending from October to April and the low season from May to September. Sampling was carried out at each first fortnight of April, June (low-water-level season) and December (highwater-level season) of 1996 and January (high-water-level season) of 1997. Samples were collected by electrofishing (Honda EX 1000 generator, 220V, 2-3A, CA) according to the sample design presented by Mazzoni et al. (2000). During each sampling, we tried to collect enough specimens to obtain a robust analysis. Unfortunately, however, when the water was high, the speed of the rapids hampered our sampling efforts.

After capture, fish were immediately fixed (formalin 10\%) and transported to the laboratory for identification and processing. Two-hundred-thirty-one individuals were analyzed, of which 55 were $C$. atrisignum, 57 were $A$. bimaculatus, 61 were Bryconamericus sp. and 58 were $M$. dichroura (Table I). Voucher specimens of each species are available in the ichthyological collection of Museu Nacional do Rio de Janeiro (MNRJ -36169 to 36172). For each sampled specimen we first registered standard length $(\mathrm{Sl}, \mathrm{cm})$ and total weight (Wt, gr). We then removed its stomach after performing an abdominal incision. Stomach content analysis was performed under a stereomicroscope through the volumetric (Vo) and frequency of occur-

Table I. Number of analyzed stomachs (N), fish length interval (SI) and Alimentary Importance Index (IAi) of each food item, considering allochthonous and autochthonous items, consumed by M. dichroura, C. atrisignum, A. bimaculatus, and Bryconamericus sp. from Cavalo stream at each sampling month. (Apr) April of 1996, (Jun) June of 1996, (Dec) December of 1996, (Jan) January of 1997. April, June, and January correspond to the high water season whereas June correspond to the low water season.

\begin{tabular}{|c|c|c|c|c|c|c|c|c|c|c|c|c|c|c|c|c|}
\hline \multirow{2}{*}{ Species } & \multicolumn{4}{|c|}{ Moenkausia dichroura } & \multicolumn{4}{|c|}{ Creagrutus atrisignum } & \multicolumn{4}{|c|}{ Astyanax bimaculatus } & \multicolumn{4}{|c|}{ Bryconamericus sp. } \\
\hline & Apr & Jun & Dec & Jan & Apr & Jun & Dec & Jan & Apr & Jun & Dec & Jan & Apr & Jun & Dec & Jan \\
\hline $\mathrm{N}$ & 10 & 28 & 10 & 10 & 7 & 25 & 18 & 5 & 12 & 27 & 12 & 6 & 11 & 31 & 9 & 10 \\
\hline $\mathrm{SI}(\mathrm{cm})$ & \multicolumn{4}{|c|}{$4.7-5.2$} & \multicolumn{4}{|c|}{$5.6-6.3$} & \multicolumn{4}{|c|}{$5.1-7.1$} & \multicolumn{4}{|c|}{$6.3-7.4$} \\
\hline \multicolumn{17}{|l|}{ Allochthonous Items (IA $)$} \\
\hline Terrestrial Insects Pupae & 6.5 & 5.9 & 4.1 & 5.5 & - & - & - & - & - & - & - & - & - & - & - & - \\
\hline Coleoptera & - & - & 1.1 & - & - & - & - & - & 5.8 & 6.3 & 6.1 & 7.2 & - & - & - & - \\
\hline Hemiptera & 0.4 & 0.9 & 1.0 & 1.1 & - & - & - & - & - & - & - & - & 22.3 & 21.7 & 20.4 & 21.5 \\
\hline \multicolumn{17}{|l|}{ Autocthonous Items $\left(\mathrm{IA}_{\mathrm{i}}\right)$} \\
\hline Coleoptera Larvae & - & - & - & - & - & - & - & - & - & - & - & - & 5.0 & 3.1 & 2.7 & 3.3 \\
\hline Ephemeroptera Nymph & 49.7 & 48.7 & 50.2 & 49.1 & 15.9 & 16.7 & 12.1 & 16.2 & 0.3 & 0.6 & 1.0 & 0.5 & 6.1 & 6.3 & 6.1 & 6.8 \\
\hline Chironomidae Larvae & 10.1 & 9.5 & 7.1 & 9.1 & 54.0 & 50.0 & 52.2 & 49.8 & - & - & - & - & - & - & - & - \\
\hline Simuliidae Larvae & - & - & - & - & - & - & - & - & 0.8 & 0.6 & 1.1 & 0.4 & 0.8 & 1.1 & 1.3 & 1.1 \\
\hline Trichoptera Larvae & 20.0 & 22.5 & 25.0 & 22.9 & 30.1 & 33.3 & 35.5 & 34.0 & 0.1 & - & - & 0.2 & 50.1 & 52.4 & 53.2 & 51.6 \\
\hline Non identified Larvae & - & - & - & - & - & - & - & - & 8.2 & 8.8 & 8.9 & 8.5 & - & - & - & - \\
\hline Vegetal Matter & - & - & - & - & - & - & - & - & 8.9 & 8.4 & 8.0 & 8.8 & - & - & - & - \\
\hline Scales & - & - & - & - & - & - & - & - & 6.0 & 6.6 & 6.8 & 7.0 & - & - & - & - \\
\hline$\%$ Allochthonous & 15.1 & 15.7 & 13.2 & 15.1 & - & - & - & - & 75.7 & 75.0 & 74.2 & 74.4 & 37.2 & 37.1 & 36.7 & 37.2 \\
\hline$\%$ Autochthonous & 84.9 & 84.3 & 86.8 & 84.9 & 100.0 & 100.0 & 100.0 & 100.0 & 24.3 & 25.0 & 25.8 & 25.6 & 62.8 & 62.9 & 63.3 & 62.8 \\
\hline
\end{tabular}


rence (Fo) methods according to Hyslop (1980) and Bowen (1992). Food items were classified to the lowest taxonomic categories following Pérez (1988). The relative importance of each food item was assessed using the percentage values of the Alimentary Index ( $\mathrm{AI}_{\mathrm{i}}-\mathrm{KAWAKAMI} \&$ VAZZOLER 1980) as follows: $\mathrm{AI}_{\mathrm{i}}=\left[\mathrm{Fo}_{\mathrm{i}} \times \mathrm{Vo}_{\mathrm{i}} / \Sigma\left(\mathrm{Fo}_{\mathrm{i}} \times \mathrm{Vo}_{\mathrm{i}}\right)\right] \times 100$, where $\mathrm{i}=1,2, \ldots . \mathrm{n}$ food items; $\mathrm{Fo}_{\mathrm{i}}=$ frequency of occurrence $(\%)$ of a given item; $\mathrm{Vo}_{\mathrm{i}}=$ volume (\%) of a given item.

Differences in dietary patterns occurring during the two hydrological seasons (four months) were tested for each species using the Spearman test (Statistica 11 - www.statsoft.com). When no differences were registered among the four sampling months, the data set was grouped for further analysis. Patterns of diet similarity, based on the AIi matrix of the four studied species, were assessed by a Bray Curtis cluster analysis (UPGMA distances) (McCune \& MefFord 1997).

Diet breadth was assessed by the Levin's niche breadth index (B), where $B=1 / \Sigma p^{2} j$, pj is the proportion of individuals using the resource j. (Krebs 1989). The Levin's index varies from 0 (diet specialized in few prays) to 1 (generalist diet). Diet overlap was calculated using the Horn index $\left(\mathrm{R}_{\mathrm{o}}\right)$ as follows: $\operatorname{Ro}=(\Sigma($ pij + pik $) \log ($ pij + pik $)-\Sigma$ pij logpik $) / 2 \log 2$ (KREBS 1989), where pij is the proportion of resource $i$ compared to all resources used by species $j$ and pik is the proportion of resource i compared to all resources used by species k. Following Zaret \& Rand (1971) and Johnson \& ARUNachalam (2012), overlap values that were higher than 0.6 were considered significant.

\section{RESULTS}

The four studied species were abundant in the study area and occurred in both hydrological seasons (high and low-tide seasons) and provided enough stomach-content data (at least five individuals/species) to conduct the analyses. There were no significant differences in the general feeding pattern of all species between the hydrological seasons - Speaman rank correlation coefficients " $\mathrm{r}_{\mathrm{s}}$ " ZAR (1999) were always higher than 0.9 for $\mathrm{p}<0.05$ (Table I). As a consequence, we grouped all data for the subsequent analyses (Table II).

The diet of $M$. dichroura was composed mainly of Diptera larvae (49.4\%), followed by Trichoptera larvae (22.0\%). The main components of the diet of C. atrisignum were Chironomidae larvae (51.5\%) and Trichoptera (33.2\%), whereas A. bimaculatus consumed mainly Hymenoptera (68.2\%). The diet of Bryconamericus sp. was mostly based on Trichoptera larvae (51.3\%) and Hemiptera (21.5\%). Autochthonous items dominated the diet of $M$. dichroura (84.6\%) and Bryconamericus sp. (63.0\%), and composed $100 \%$ of the diet of C. atrisignum. Allochthonous items dominated the diet of $A$. bimaculatus (74.6\%) (Table II).

Trophic niche breadth (Fig. 1) varied among species. The greatest values were registered for $M$. dichroura (0.48) followed by Bryconamericus sp. (0.39), A. bimaculatus (0.33) and C. atrisignum (0.29).

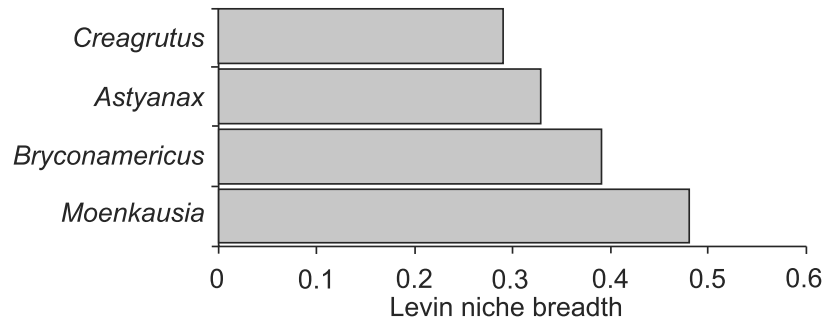

Figure 1. Niche breadth of Moenkhausia dichroura, Creagrutus atrisignum, Astyanax bimaculatus and Bryconamericus sp. from Cavalo stream.

Table II. Number of analyzed stomachs $(\mathrm{N})$ and Alimentary Importance Index $\left(I A_{i}\right)$ of each food item from allochthonous and autochthonous origim, consumed by $M$. dichroura (MD), $C$. atrisignum (CA), A. bimaculatus (AB) and Bryconamericus sp. (BSP) from Cavalo stream. Pooled data for all sampled month.

\begin{tabular}{lcccc}
\hline \multicolumn{1}{c}{ Species } & MD & CA & AB & BSP \\
\hline $\mathrm{N}$ & 58 & 55 & 57 & 61 \\
\hline Allochthonous Items (IA $)$ & & & & \\
$\quad$ Terrestrial Insects Pupae & 5.4 & - & - & - \\
Hymenoptera & 8.0 & - & 68.2 & 15.5 \\
Coleoptera & 1.1 & - & 6.4 & - \\
Hemiptera & 0.9 & - & - & 21.5 \\
\hline Autocthonous Items (IA $\left.{ }_{i}\right)$ & & & & \\
Coleoptera Larvae & - & - & - & 3.5 \\
Ephemeroptera Nymph & 49.4 & 15.1 & 0.6 & 6.3 \\
Odonata Nymph & 4.3 & 0.2 & 0.2 & 0.8 \\
Chironomidae Larvae & 9.0 & 51.5 & - & - \\
Simuliidae Larvae & - & - & 0.7 & 1.1 \\
Trichoptera Larvae & 22.0 & 33.2 & 0.2 & 51.3 \\
Non identified Larvae & - & - & 8.6 & - \\
Vegetal Matter & - & - & 8.5 & - \\
Scales & - & - & 6.6 & - \\
\hline \% Allochthonous & 15.4 & & 74.6 & 37.0 \\
\% Autocthonous & 84.6 & 100.0 & 25.4 & 63.0 \\
\hline
\end{tabular}

Similarity analysis revealed two groups with different patterns of food preference. The first group was formed exclusively by invertivorous species and included M. dichroura, Bryconamericus sp., and C. atrisignum. The second group was composed of a single omnivorous species (A. bimaculatus). Nonetheless, group 1 was further subdivided into two subgroups. The diet of the species in the first group (M. dichroura and Bryconamericus sp.) contained both autochthonous and allochthonous items. By contrast, the second subgroup contained species that eat exclusively autochthonous items $(C$. atrisignum) (Fig. 2). We detected significant (overlap $>0.6$ according to ZARET \& RAND 1971) feeding overlap in three (75\%) of the four pairs of species analyzed (Table III). 


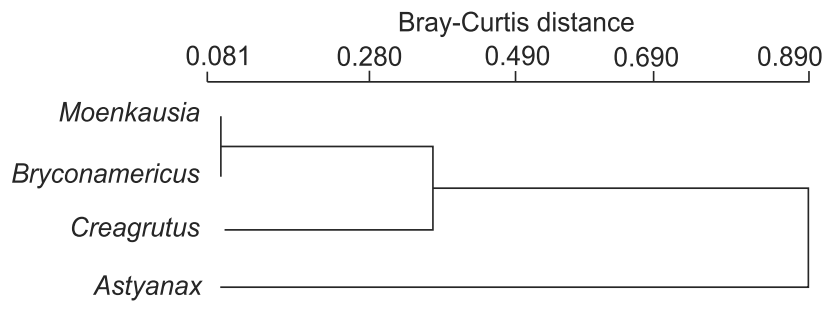

Figure 2. Similarity dendrogram based on diet composition of four species of fish analyzed in Cavalo stream.

Table III. Horn Index values (diet overlap) among the four Characidae species: $M$. dichroura (MD), C. atrisignum (CA), A. bimaculatus (AB), and Bryconamericus sp. (BSP) from Cavalo stream. * Values $>0.60$ represent significant overlap according to Zaret \& Rand (1971) and Johnson \& Arunachalam (2012).

\begin{tabular}{clcc}
\hline & $C A$ & $A B$ & $B S P$ \\
\hline$A B$ & 0.29 & - & - \\
$B S P$ & $0.74^{*}$ & 0.31 & - \\
$M D$ & $0.69^{*}$ & 0.36 & $0.73^{*}$ \\
\hline
\end{tabular}

\section{DISCUSSION}

Species of Characidae, such as those studied in the present paper, are largely widespread through the Neotropics and Central America (Reis et al. 2003, BucKup et al. 2007, LIMA et al. 2007) and have been classified into different feeding guilds, for instance insectivorous (e.g., CASATTI et al. 2003, SANTOS et al. 2009, Bonato et al. 2012), herbivorous (e.g., Meschiatti 1995, Cassemiro et al. 2002) and omnivorous (e.g., CASSEMIRO et al. 2002, BRANDãoGonçalves et al. 2009, Rondinel et al. 2011), changing feeding habits according to the environment in which they occur. Our results showed that the diet of the four species studied is largely insectivorous, based both on autochthonous and allochthonous items, and that there are no seasonal differences related to the hydrological regimen. Other studies conducted in Neotropical streams also showed that small Characidae species frequently feed on invertebrates, and include both autochthonous and allochthonous items in their diets (TANK et al. 2010, Ortaz et al. 2011, Rondineli et al. 2011, Ximenes et al. 2011, Bonato et al. 2012, ManNa et al. 2012).

Streams that run through dense forests have low light levels due to the closed canopy. Consequently, the input of allochthonous organic matter (ARAújo-Lima et al. 1995) and terrestrial arthropods (Rezende \& MAZzoni 2003, Moulton 2006) in these streams often outweighs the autochthonous algal production (VANNote et al. 1980, Henry et al. 1994, Thorp 2002, TANK et al. 2010), affecting fish diet, as well as the entire trophic web (DodDs 2007). Thus, the input of allochthonous matter (animal and vegetal) is an important determinant of the dynamics of a stream, because it provides food for both fish and micro/macro-invertebrates, which in turn are food resources for many other stream-dwelling organisms. The importance of such allochthonous matter as an energy source flowing through the food chain was demonstrated for both Temperate (FIsHer \& Likens 1973, Vannote et al. 1980, McIntire \& Flecker 2010) and Tropical (Gonçalves et al. 2006, Moulton 2006, Selva et al. 2007) streams. In conclusion, the contribution of allochthonous material, as a direct or indirect source of food for fish, has been shown to be very important in streams, as the one studied in the present work (e.g., Henry et al. 1994, UiEDA \& КікUCHI 1995, Mazzoni \& Rezende 2003, Rezende \& Mazzoni 2003).

We observed that among the four species studied, three feed mainly on autochthonous and one consumed mainly allochthonous items. These results indicate that both allo- and autochthonous processes are operating in the maintenance of the stream-dwelling fish community. Similar results had been previously documented for other tropical systems (e.g., Alvim \& PERET 2004) and could confirm the relative importance of different sources of energy to streams in Tropical areas. Nonetheless, based on dietary overlap and similarity analysis, we registered that $50 \%$ of the analysed species pairs used similar food resources. Among the four co-existing Characidae, three species used the same food resource (autochthonous matter).

Several reports on the feeding ecology of stream-dwelling fishes have shown that an overlap in resource use does not necessarily imply that there is competition among the species involved, since temporal and spatial segregation are strategies that minimize direct confrontation in the use of resources (CASATTi 2002, Kotler \& BRown 2007). Three species in our study (M. dichroura, C. atrisignum and Bryconamericus sp.) shifted among insect prey. They all preyed almost exclusively on autochthonous items and their diets overlapped in about $50 \%$ of the items. Moenkausia dichroura preyed mainly on larvae of Ephemeroptera (48.75), C. atrisignum preyed mainly on larvae of Chironomidae (50\%) and Bryconamericus sp. preyed mainly on larvae of Trichoptera (52.4\%). Such strategy could reflect the specific morphological adaptations of each species and/or their use of the microhabitat (CASATTI \& Castro 2006, Mazzoni et al. 2010) and could explain the co-existence of these close related species. Although resource availability was not measured in the present study, we suppose that the available prey items were diverse enough to allow for the observed feeding patterns of these Characidae fish species.

Studies in Amazonian streams showed that the diet of almost all fish species that shared a food source consisted of allochthonous plants or allochthonous insects (LoweMcConnell 1999). These findings reveal that the similarity in the use of feeding resources may be a consequence of the wide availability of them and/or a consequence of their shared use. Several examples of studies in Amazonian and other river systems in the Neotropical region have shown that this alternative is valid and recurrent (e.g., SABINO \& ZUANON 1998, CASATTI 2002, NovakowsKi et al. 2008, Rolla et al. 2009). Based on previ- 
ous data on community persistence and the temporal maintenance of the densities of the four studied species in the Cavalo Stream (Miranda \& MAZzoni 2009), we suggest that these species share unlimited resources, and that competition is not regulating their populations.

\section{ACKNOWLEDGEMENTS}

We thank Ricardo Iglesias Rios and anonymous referee for critical reading and suggestions on the first draft of the manuscript and all members of the Laboratório de Ecologia de Peixes, UFRJ and UERJ for assistance with field work and processing of the material. This work was done through the contract Serra da Mesa Energia-Furnas/BioRio/UFRJ, UERJ agreement.

\section{LITERATURE CITED}

Alvim, M.C.C. \& C.A. Peret. 2004. Food resources sustaining the fish fauna in a section of the upper são Francisco River in Três Marias, MG, Brazil. Brazilian Journal of Biology 64: 195-202.

Aranha, J.M.R.; D.F. Takeuti \& T.M. Yoshimura. 1998. Habitat use and food partitioning of the fishes in a coastal stream of Atlantic Forest, Brazil. Revista Biologia Tropical 46: 955963.

Aranha, J.M.R.; J.H.C. Gomes \& F.N.O Fogaça. 2000. Feeding of two sympatric species of Characidium, C. lanei and $C$. pterostictum (Characidiinae) in a coastal stream of Atlantic Forest (Southern Brazil). Brazilian Archieves of Biology and Technology 43: 527-531.

Araújo-Lima, C.A.R.M.; A.A. Agostinho \& N.N. Fabré. 1995. Trophic aspects of fish communities in Brazilian rivers and reservoirs, p. 105-136. In: D. Tundisi; C.E.M. Bicudo \& T. Matsumura-Tundisi (Eds). Limnology in Brazil. Rio de Janeiro, Brazilian Academy of Sciences, Brazilian Limnological Society, XVII+384p.

Balassa, G.C.; R. Fugi; N.S. Hahn \& A.B. Galina. 2004. Dieta de espécies do Anostomidae (Teleostei, Characiformes) na área de influência do reservatório de Manso, Mato Grosso, Brasil. Iheringia, Série Zoologia, 94: 77-82.

Bonato, K.O.; R.L. Delariva \& J.C. Silva. 2012. Diet and trophic guilds of fish assemblages in two streams with different anthropic impacts in the northwest of Paraná, Brazil. Zoologia 29: 27-38.

Bowen, S.H. 1992. Quantitative description of the diet, p. 325336. In: L.A. Nielsen \& D.L. Johnson (Eds). Fisheries Techniques. Maryland, American Fisheries Society, IX+468p.

Brandão-Gonçalves, L.; S.E. Lima-Junior \& Y.R. Suarez. 2009. Hábitos alimentares de Bryconamericus stramineus Eigenmann, 1908 (Characidae), em diferentes riachos da sub-bacia do Rio Guiraí, Mato Grosso do Sul, Brasil. Biota Neotropica 9: 135-143.
Britski, H.A.; K.Z.S. Silimon \& B.S. Lopes. 1999. Peixes do Pantanal: manual de identificação. Brasília, Embrapa-Spi, XIX+909p.

Buckup, P.A.; N.A. Menezes \& M.S. Ghazzi. 2007. Catálogo das espécies de peixes de água doce do Brasil. Rio de Janeiro, Museu Nacional, 195p.

Caramaschi, E.P.; R. Iglesias-Rios \& R. Mazzoni. 2012. Caracterização e dinâmica da área e métodos de amostragem, p. 1752. In: R. Mazzoni; E.P. Caramaschi \& R. Iglesias-Rios (Eds). Usina Hidrelétrica de Serra da Mesa: 15 anos de Estudos da Ictiofauna do Alto Tocantins. Rio de Janeiro, Furnas Centrais Elétricas, 386p.

Casatti, L. 2002. Alimentação dos Peixes em um Riacho do Parque Estadual Morro do Diabo, Bacia do Alto Rio Paraná, Sudeste do Brasil. Biota Neotropical 2: 1-14.

Casatti, L.; H.F. Mendes \& K.M. Ferreira. 2003. Aquatic macrophytes as feeding site for small fishes in the Rosana reservoir, Paranapanema River, Southeastern Brazil. Brazilian Journal of Biology 63: 213-222.

Casatti, L. \& R.M.C. Castro. 2006. Testing the ecomorphological hypothesis in a headwater riffles fish assemblage of the rio São Francisco, southeastern Brazil. Neotropical Ichthyology 4: 203-214.

CASSEmiro, F.A.S.; N.S. Hahn \& R. Fugi. 2002. Avaliação da dieta de Astyanax altiparanae Garutti and Britski, 2000 (Osteichthyes, Tetragonopterinae) antes e após a formação do reservatório de Salto Caxias, Estado do Paraná, Brasil. Acta Biologica Scientiarum 24: 419-425.

Chase, J.M. \& M.A. Leibold. 2003. Ecological niches: linking classical and contemporary approaches. Chicago, University of Chicago Press, 212p.

DoDDs, W.K. 2007. Trophic state, eutrophication and nutrient criteria in streams. Trends in Ecology and Evolution 22: 669676.

Douglas, M.E. \& W.J. MatThews. 1992. Does morphology predict ecology? Hypothesis testing within a freshwater fish assemblage. Oikos 65: 213-224.

Douglas, M.E.; P.C. Marsh \& W.L. Minckley. 1994. Indigenous fishes of western North America and the hypothesis of competitive displacement: Meta fulgida (Cyprinidae) as a case study. Copeia 1: 9-19.

FisHeR, S.G. \& G.E. Likens. 1973. Energy flow in Bear Brook, New Hampshire: An integrative approach to stream metabolism. Ecological Monographs 43: 421-439.

Dyer, L.A.; T.R. Walla; H.F. Greeney; J.O. Stireman \& R.F. Hazen. 2010. Diversity of Interactions: A Metric for Studies of Biodiversity. Biotropica 42: 281-289.

Fisher, S.G. \& G.E. LiKENs. 1973. Energy flow in Bear Brook, New Hamsphire: An integrative approach to stream ecosystem metabolism. Ecological Monographs 43: 421-439.

Gonçalves Jr, J.F.; J.S. França \& M. Callisto. 2006. Dynamics of allochthonous organic matter in a tropical Brazilian headstream. Brazilian Archives of Biology and Technology 49: 967-973. 
Gravel, D.; C.D. Canham; M. Beaudet \& C. Messier. 2006. Reconciling niche and neutrality: the continuum hypothesis. Ecology Letters 9: 399-409.

Henry, R.; V.S. UiedA; A.A. Afonso \& R.M. KiкUCHI. 1994. Input of allochthonous matter and structure of fauna in Brazilian headstream. Verhandlungen der Internationalen Vereinigung fur Theoretische und Angewandte Limnologie 25: 1867-1869.

Hubbell, S.P. 2001. The Unified Neutral Theory of Biodiversity and Biogeography. Princeton, Princeton University Press, $448 p$.

Hurlbert, S.H. 1978. The measurement of niche overlap and some relatives. Ecology 59: 67-77.

HyNES, H.B.N. 1970. The ecology of running waters. Liverpool, University Press, XXIV+555p.

Hyslop, E.J. 1980. Stomach contents analysis - a review of methods and their application. Journal of Fish Biology 17: 411-429.

Johnson, J.A. \& M. Arunachalam. 2012. Feeding habit and food partitioning in a stream fish community of Western Ghats, India. Environmental Biology of Fishes 93: 51-60.

KaWAKami, E. \& G. Vazzoler. 1980. Método gráfico e estimativa de índice alimentar aplicado no estudo da alimentação de peixes. Boletim do Instituto Oceanográfico 29: 205-207.

Krebs, C.J. 1989. Ecological Methodology. New York, Harper Collins Publishers, XX+620p.

KotLerr, B.P. \& J.S. Brown. 2007. Community Ecology, p. 397-434. In: D.A Stephens; J.S. Brown \& R.C. Ydenberg (Eds). Foraging: Behavior and Ecology. Chicago, University of Chicago Press.

Leibold, M.A. \& M.A. McPeer. 2006. Coexistence of the niche and neutral perspectives in community ecology. Ecology 87: 1399-1410.

Lima, F.C.T.; P.A. Buckup; N.A. Menezes; C.A.S. Lucena; Z.M.S. Lucena; M. Toledo-Piza \& A. Zanata. 2007. Família Characidae: gêneros incertae sedis, p. 44-62. In: P.A. BucKUP; N.A. Menezes \& M.S. Ghazzi (Eds). Catálogo das espécies de peixes de água doce do Brasil. Rio de Janeiro, Museu Nacional, XXII+195p.

Lowe-McConnell, R.H. 1999. Estudos ecológicos de comunidades de peixes tropicais. São Paulo, Edusp, XIIIV+535p.

Manna, L.R.; C.F. Rezende \& R. Mazzoni. 2012. Plasticity in the diet of Astyanax taeniatus in a coastal stream from southeast Brazil. Brazilian Journal of Biology 72: 919-928.

Mazzoni, R.; N. Fenerich-Verani \& E.P. Caramaschi. 2000. Electrofishing as a sampling technique for coastal stream fish populations and communities in the southeast of Brazil. Revista Brasileira de Biologia 60: 205-216.

Mazzoni, R. \& C.F. Rezende. 2003. Seasonal diet shift in a Tetragonopterinae (Osteichthyes, Characidea) from Ubatiba river, RJ, Brazil. Brazilian Journal of Biology 63: 69-74.

Mazzoni, R.; M. Moraes; C.F. Rezende \& J.C. Miranda. 2010. Alimentação e padrões ecomorfológicos das espécies de peixes de riacho do alto rio Tocantins, Goiás, Brasil. Iheringia, Série Zoologia, 100: 162-168.
McCune, B. \& M.J. Mefford. 1997. PC-ORD. Multivariate Analysis of Ecological Data. Oregon, MjM Software.Gleneden Beach,Version 3,0.

McIntyre, P.B \& A.S. Flecker. 2010. Ecological Stoichiometry as an integrative Framework in Stream Fish Ecology. American Fisheries Society Symposium 73: 539-558.

Meschiatti, A.J. 1995. Alimentação da comunidade de peixes de uma lagoa marginal do rio Mogi-Guaçu - SP. Acta Limnologica Brasiliensis 7: 15-137.

Mikrelson, G.M. 2005. Niche-Based vs. Neutral Models of Ecological Communities. Biology and Philosophy 20: 557566.

Miranda, J.C. \& R. Mazzoni. 2003. Composição da ictiofauna de três riachos do alto rio Tocantins, GO. Biota Neotropica 3: $1-11$.

Miranda, J.C. \& R. Mazzoni. 2009. Estrutura, composição e persistência temporal da comunidade de peixes de três riachos do alto rio Tocantins, GO. Biota Neotropica 9: 71-78.

MotTA, R.S. \& V.S. UiEDa. 2004. Dieta de duas espécies de peixes do ribeirão do Atalho, Itatinga, SP. Revista Brasileira de Zoologia 6: 191-205.

Moulton, T.P. 2006. Why the world is green, the waters are blue and food webs in small streams in the Atlantic rainforest are predominantly driven by mricoalgae? Oecologia Brasiliensis 10: 78-89.

Nelson, J.S. 1994. Fishes of the world. New York, John Wiley and Sons, XVII+600p.

Nobis, M. \& T. WoHLgEmuth. 2004. Trend words in ecological journals over the last 25 years (1978-2002). Oikos 106: 411-421.

Novakowski, G.C.; N.S. HaHn \& R. FugI. 2008. Diet seasonality and food overlap of the fish assemblage in a pantanal pond. Neotropical Ichthyology 6: 567-576.

Ortaz, M.; R. Martín \& A. López-Ordaz. 2011. Variación espacial y temporal en la composición de la dieta de peces invertívoros en un río neotropical, Venezuela. Revista de Biologia Tropical 59: 1217-1231.

PÉREZ, G.R. 1988. Guía para el estudio de los macroinvertebrados acuáticos del Departamento de Antioquia. Bogotá, Universidad de Antioquia, VI+217p.

Poullly, M.; F. Lino; J.G. Bretenoux \& C. Rosales. 2003. Dietarymorphological relationships in a fish assemblages of the Bolivian Amazonian floodplain. Journal of Fish Biology 62: 1137-1158.

Pouilly, M.; T. Yunoki; C. Rosales \& L. Torres. 2004. Trophic structure of fish assemblages from Mamoré River floodplain lakes (Bolivia). Ecology of Freshwater Fish 13: 245-257.

Pouilly, M.; S. BarRera \& C. Rosales. 2006. Changes of taxonomic and trophic structure of fish assemblages along an environmental gradient in the Upper Beni watershed (Bolivia). Journal of Fish Biology 68: 37-156.

Reis, R.E.; S.O. Kullander \& C.J. Ferraris-Jr. 2003. Check list of the freshwater fishes of South and Central America. Porto Alegre, Edipucrs, XI+729p. 
Rezende, C.F. \& R. Mazzoni. 2003. Aspectos da alimentação de Bryconamericus microcephalus (Characiformes, Tetragonopterinae) no Córrego Andorinha, Ilha Grande, RJ. Biota Neotropica 3: 1-6.

Rolla, A.P.P.R.; K.E. Esteves \& A.O. Ávila-DA-Silva. 2009. Feeding ecology of a stream fish assemblage in na Atlantic Forest remnant (Serra do Japi, SP, Brazil). Neotropical Ichthyology 7: $65-76$

Rondineli, G.; L.M. Gomiero; A.L. Carmassi \& F.M.S. Braga. 2011. Diet of fishes in Passa Cinco stream, Corumbataí River subbasin, São Paulo state, Brazil. Brazilian Journal of Biology 71: 157-167.

Ross, S.T. 1986. Resource partitioning in fish assemblages: A review of field studies. Copeia 2: 352-388.

Sabino, J. \& J. Zuanon. 1998. A stream fish assemblage in Central Amazonia: distribution, activity patterns and feeding behavior. Ichthyological Exploration of Freshwaters 8: 201-210.

Santos, C.L.; I.A. Santos \& C.J. Silva. 2009. Ecologia trófica de peixes ocorrentes em bancos de macrófitas aquáticas na baia Caiçara, Pantanal Mato-Grossense. Brazilian Journal of Biology 7: 473-476.

Schoener, T.W. 1974. Resource partitioning in ecological communities. Science 185: 27-39.

Selva, E.C.; E.G. Couto; M.S. Johnson \& J. Lehmann. 2007. Litterfall production and ûuvial export in headwater catchments of the southern Amazon. Journal of Tropical Ecology 23: 329-335.

TANK, J.L.; E.J. Rosi-Marshall; N.A. Griffiths; S.A. EnTReKIN \& M.L.
Stephen. 2010. A review of allochthonous organic matter dynamics and metabolism in streams. Journal of the North American Benthological Society 29: 118-146.

Thorp, J.H. 2002. Dominance of autochthonous autotrophic carbon in food webs of heterotrophic rivers. Oikos 93: 543550.

Uieda, V.S. \& R.M. KiKUchi. 1995. Entrada de material alóctone (detritos vegetais e invertebrados terrestres) num pequeno curso de água corrente na costa de Botucatu, São Paulo. Acta Limnologica Brasiliensis 7: 105-114.

Uieda, V.S.; P. Buzzato \& R.M. Kikuchi. 1997. Partilha de recursos alimentares em peixes em um riacho de serra do Sudeste do Brasil. Anais da Academia Brasileira de Ciências 69: 243-252.

Vannote, R.L.; G.W. Minshall; K.W. Cummins; J.R. Sedell \& C.E. Cushing. 1980. The river continuum concept. Canadian Journal of Fisheries and Aquatic Science 37: 130-137.

Vojtech, N.; Y. Basset; S.E. Miller; G.D. Weiblen; B. Bremer; L. CizeK \& P. DrozD. 2002. Low host specificity of herbivorous insects in a tropical forest. Nature 416: 841-844.

Ximenes, L.Q.L.; L.A.F. Mateus \& J.M.F. Penha. 2011. Variação temporal e espacial na composição de guildas alimentares da ictiofauna em lagoas marginais do Rio Cuiabá, Pantanal Norte. Biota Neotropica 11: 205-215.

ZARET, T.M. \& A.S. RAND. 1971. Competition in tropical stream fishes: Support for the competitive exclusion principle. Ecology 52: 336-342.

ZAR, J.H. 1999. Biostatistical Analysis. Englewoods Cliffs, Prentice Hall, 662p.

Submitted: 27.IX.2012; Accepted: 14.IX.2013.

Editorial responsibility: Vinicius Abilhoa 